POLISH POLITICAL SCIENCE

VOL XLI 2012

PL ISSN 0208-7375

\title{
DEBATING THE CONCEPT OF “GOOD LAW"
}

\author{
by Krzysztof Pałecki
}

Establishing good law has been an old dream of humanity. Back in ancient times leaders such as Hammurabi, Solon, and especially Justinian the Great, and many others, while attempting to codify and reform the law, were driven by the ideal of "good law". This same idea inspired Montesquieu in his De l'esprit des lois ("The Spirit of the Laws"). Monumental legal acts in Napoleon's times or the time of German unification, as well as copying these acts into the legal systems of the countries of the Far East, for example, Japan, serve as additional examples on how tempted leaders have been able to implement the idea of "good law", which, quite frequently, is directly stated in the preamble to leading legal acts.

Today, the idea of "good law" can be found in almost all programs of more ambitious social organizations or political parties. This holds true especially for organizations with strong aspirations for social reform. The concept of "good law" has also received adequate reflection from such prominent academic legal thinkers as Lon L. Fuller (1978), Herbert Hart (1977), Jospeh Raz (1979), Gustav Radbruch (2009), Robert Alex (2007) and many others.

Although an analysis of justifications of numerous parliamentary bills and the works of their commentators, which are dogmatic and legal in 
nature, and which are written with a more or less intended objective to "cure the law" is beyond the scope of this paper, a certain generalization needs to be made: the greater the dynamics of social change, and the more rapid and radical this process is, the more expressed is the "program" postulate to change the law, or at least to "cure" it, "fix" it, or create it anew; all, without doubt, to make it "better", "more just" "more adequate", " more modern", "more effective", "more legitimate" (or right), " better representing interests" etc., etc. More than anything else the driving force behind these attempts is the desire to reach this, more or less explicit, ideal of "good law". Numerous examples supporting this argument can be found in postulates, programs, and projects for legal reforms put forward during the system of transition in Eastern and Central European countries in the last two decades of the $20^{\text {th }}$ century.

Interestingly, none of these attempts has yet received an adequate amount of general reflection over the unquestionable postulate of "good law". That is why, in line with the presented argumentation, it seems enough for anybody attempting to establish and implement such "good" law to simply offer a guarantee that the desired social, economic and political order will be reached and maintained. Hence, a question: is such belief in the causative power of law, and even its omnipotence, fully justified given the theoretical knowledge and empirical evidence obtained in areas such as sociology of law, political science, economics, and more? Despite the importance of this issue, for the moment, it needs to be put aside. The subject of this analysis focuses on the issue of what is "good law" and whether this concept is possible to implement.

Already in the early stage of the analysis serious problems with terminology start to emerge. They all bring real consequences which primarily arise from different understandings of law. In order to avoid an unnecessary confusion, some understandings of the concept of law, which are less relevant for the purpose of this analysis, will be omitted. They include: the concept of law as a form of psychological experience (for example the imperative-attributive emotions postulated by Leon Petrażycki), law as a "practice of local community" (for example Eugen Ehrlich's "living law"), law as judicial decisions (as postulated by American realists), or - earlier - law as a "sui generis social fact" (compare Emil Durkheim's theory) and 
many others. While none of these approaches is the subject of this analysis, it could nonetheless be interesting - although in each case for different reasons, to at least undertake a discussion on the possibility of recreating - within the framework of these approaches - the methods and techniques proposed within them to improve law and different ways of its intentional transformation to comply with the ideal of "good law".

Such "reduction" among available definitions - performed for the purpose of scope of this analysis - allows an observation of two, still alive, traditions of understanding the law. First, of positivist origin, is the approach which leans towards the understanding of law as a collection (system) of legal regulations which are binding in a particular state (politically organized society) in marked physical territory and time. The binding nature of these acts, that is their "legal" nature, is formally presupposed (prejudged) by fulfilling a procedural process of their making (for example lawmaking procedures). Due to the scope of this analysis, it can only be highlighted that such seemingly obvious designators of the concept of "law" may create numerous problems once looked at more deeply. A more curious reader should refer to other works on the subject, including a recent publication of Andrzej Grabowski (2009).

Despite many doubts, it is certain that, in this tradition, the designator of "law" is a collection of written statements of a specific origin, meaning, a way of articulation and ordering.

The second tradition is of sociological (sociological-legal) origin, but has also greatly benefited from the theories developed within political science (as well as in other areas of the inquiry such as the theory of organization). From this perspective, "law" means also, or maybe first of all, institutions which make, apply and execute regulations (norms) included in the above mentioned collection of statements. Hence, institutions which are not understood - as often encountered in legal language - as more or less coherent content (meaning) of one-subject regulations (norms), placed in legal acts, but rather according to a distinction once made by Tomasz Gizbert Studnicki (2001:130) who regarded institutions, similarly to theories in the anthropology of culture, as organizationally and materially distinguished groups of people with specific skills and with normatively established competence, fulfilling, usually professionally, 
particular functions in the framework of a particular social order (see Malinowski, 2001 (1926): 19). To complete the somewhat little convincing arguments of Donald Black (1976:2 and subsequent) it is here assumed that "law" is a specific collection of actions which includes in its designators structured agents who act in a specific way (see also Adamson Hoebel, 1954:5).

On a side note, it is easily noticeable that attempts for a more precise definition of "law" in both of these understandings, will lead to a typical idem per idem mistake. According to the first understanding, "law" as statements, the requirement (condition) which decided on what is to be regarded as "law" are the other statements, which are not law (especially regulations regulating procedures of law-making). Similarly in the second understanding, where "law" is understood as institutions (their functioning and consequences) whose belonging to the "legal system" is decided by these very same institutions (for example through processes of making legal regulations which prejudge this). A combined understanding of "law", meaning particular institutions and statements remaining in ascertainable, mutually functional relations (the type of articulated legal regulations processes of applying these regulations), would allow, although only up to a certain point, to avoid, or "dodge", such a mistake. Remaining in the so-called "internal perspective of the legal system" - as coined by Hakan Hyden (2010) - allows for at least a somewhat correct definition of its certain elements (for example institutions applying law as institutions regarded as such in "specific legal regulations" without further need to prolong the "chain of definitions" for example by definition of these "legal regulations".)

Due to an obvious lack of hope to obtain a commonly accepted answer, it is probably better to leave the philosophers with this perennial question what is law. Instead, let us return to the main question of this analysis, meaning the idea of "good law". In the beginning, we can easily state that should the designator of "law" be limited only to a collection of statements (legal regulations) then the concept of "good law" would either have to have defined and desired linguistic and formal characteristics (for example a clear and precise language of articulation or a universal method of order ) or also (or only) the characteristics relating to the content (mean- 
ing) of the statement, for example being "just", "right", "rational", "justified", etc. The scope, subject and methods of legal regulations, as well as appointing adequate agents to "improve" these regulations (legal acts), that is attempts to bring particular "law" closer to the ideal of "good law," or even which already have helped fulfill this ideal in a satisfactory way, that is everything that comprises the implementation of the idea of "good law" is - at this time - entirely determined by a desired state of the form and content of normative statements. Another question arises: are legal regulations, no matter how ideally articulated in their content and how systematically organized, the guarantee in "themselves" of their adequate usage and adequate compliance? Are they the real determinant of social order as shaped by these acts? Here serious doubts arise. A sociologist of law (or anybody who accepts the sociological perspective in the reflection on law) will probably admit that the above mentioned content and formal characteristics of "law", understood as a collection of normative statements, are insufficient to name it "good law" for the mere reason of the possibility of its ineffective influence. Another reason would be the noneliminable discrepancy between the generalized, as a rule, objectives of legal regulations, assumed by the lawmaker and ad hoc, individual and specific objectives of institutions applying and executing these regulations. Undoubtedly, a radical legal positivist will claim it to be beyond the tasks included in the idea of creating a "good law". Hans Kelsen, for instance, strongly discouraged a pursuit of one specific objective of law and by doing so eliminated from the discussion the problem of law's effectiveness (1973: 34 and subsequent). And yet one can rightly point out that by making such a statement Kelsen largely and unjustifiably simplified the entire problem. The process of making "law" (in the form of legal acts and decisions which are based on them) is a product of many actions undertaken by particular institutions, including actions which are unforeseen by procedures. What is more, these actions are not free of influence of other institutions outside the legal system. The real functioning of these institutions, which all comprise a "broader" (but also real and not only formal) lawmaker, their organization, substantial equipment, competence of people employed, as well as customs and motivation, beliefs and personalities, etc. are all a meaning for the quality (technical but also in terms 
of content) of legal acts created. Accepting, all these consequences, the positivist view of law, one has to agree with a somewhat debatable statement that implementation of the concept of "good law" is fully independent of the influence of personalities, organizational and substantial characteristics of institutions which create law. This issue shall be discussed in greater detail further on in the analysis.

Nonetheless, an attempt to show a correlation between successful implementation of the concept of "good law" and the quality of legal institutions, as I suggested earlier, can be further complicated not only by the technical capability of these institutions, but also by their ethical (moral) assessment or, as some prefer, the "ethical legitimization" of lawmaking. This brings us down to the question whether a "hideous lawmaker", a "hideous political system" ("hideous judge" etc.) can make "good law", both in legislative and judicial terms? It is worth pointing out that this problem, which may give many sleepless nights to a few "legal moralists" whose argumentation reflects Radbruch's concept of the ethical legitimization of law (2009:51, 74 and subsequent), may, in fact, turn out to be quite apparent. Calling lawmakers "hideous" not for their personal characteristics but the quality of law they introduce (that is as a consequence of the negative assessment of the degree of its "goodness") becomes morally relative and possible only when this "hideous" law is already a social fact, meaning after it has started bringing real effects. Unquestionably, even before the process of lawmaking is completed, we may characterize legislative and judicial institutions (or even present personal characteristics of people employed by them) as having bad, immoral, cynical, interest-driven, egoistic, etc. motivations and intentions and also present the process of lawmaking as corrupt. Nonetheless, it should be born in mind that for the assessment of law (understood as legal regulations) created in such a way such characteristics can remain completely irrelevant. They are more a consequence of applying particular assessment criteria not to the law itself, but to these institutions or/and people. Disregarding different, irrelevant for this analysis, reasons for negative evaluations of the lawmaker (such as personal grievances, ideological beliefs, and other) the assessment of the "producer" of law should be entirely based on the quality of the "product" and this assessment, in turn, should be 
based on the social effects of the application of law. That is why, it is difficult to reject, a priori, the possibility of a situation where an otherwise "hideous" lawmaker, dishonest judge, corrupt civil servant, etc. will create, apply, and execute "good" - in its results - law. Following the same principle a "noble lawmaker" an "honest judge", and a "morally impeccable civil servant" may, just as well, create, apply, and execute "bad law".

Even if such arguments are correct, it seems that the ethical (moral) assessment of lawmakers (different than the assessment of the degree of their functionality) is not completely indifferent to the possibility of implementing the concept of "good law". Some doubts may appear from common observations and experience of the existence of a specific correlation between particular personality features of the actors and the characteristics of the consequences of their actions. That is why, we are prone to believe that morally deprived persons, even of high professional skills, cannot intentionally apply the law, which based not only on the ethical criteria, could be called "good". These contestations are not neutral for establishing the way of implementing the concept of "good law".

Going further one can notice that if "law," understood as a collection of written statements, includes both applied acts and concrete decisions (for example judicial decisions) a paradoxical situation may emerge. Both attempts to improve law and make it "better", that is to implement the concept of "good law", can only take place ex post, meaning based on existing legal texts (both in the sense of their formally binding power and as applied in legal practice). Yet, such procedures would be impossible de lege ferenda. They are possible, however, in the texts of proposed laws (for example parliamentary bills). Yet, since the latter are not law, in a sense presented in this analysis, they cannot constitute a basis for effective legal decision-making (cf. A. Grabowski, 2009:69 and subsequent), although they may become an instrument for the implementation of the concept of "good law". Even more difficult is an attempt to improve the content and forms of future decisions made in the process of the application of the law. This is not only because they do not yet exist as law but also because no one can ever be certain what their final content will turn out to be (this is especially true with the so-called hard cases). On a margin, it is worth pointing out that lack of socially postulated legal regulations 
(legal anomie) may result in their introduction, although this "gap filling" procedure does not necessarily translate into an implementation of the concept of "good law".

Everything changes, however, when the term "law" (the system of law) includes - in accordance with sociological and legal approaches - institutions which make, apply, and execute legal regulations and their real, and not only implied in the content of procedures, functioning. In terms of the implementation of the concept of "good law" this would also mean activities aimed at improving these institutions, even before they make any decisions to create legal regulations, not only through improving procedures, which would be obvious, but also through a real betterment of their work (for example by introducing better work organization, adequate technical equipment, improving workers' qualifications, etc.). The question; are any institutions, within this understanding of law (legal system), interested in such "realistic" improvement and do they have adequate qualifications, remains open to discussion. In the face of such a shortage, their creation would be yet another implementation of the concept of "good law".

Visibly, different ways of implementing the concept of "good law" get differentiated and complicated depending on the designators of the term "law". It may sound slightly trivial. However, the earlier presented reflections make less trivial the questions as who and in which way they should undertake the implementation of this concept. The popular belief stating that this is a task only for lawyers leads to, I daresay, accepting in practice the worst possible strategy of improving law. The possible source of such reasoning is a quite common monopoly on the knowledge about the practice of creating the legal order though legal regulations, which, traditionally, has been entrusted to the legal profession. Even if such an argument partially holds true, it is also true that law, regardless of its definition, is not a completely auto-creative, substantially independent and intrinsic creature. Contrary, it is, in this whole scope, dependent, although to different degrees, on political institutions and other social institutions. Hence, out of necessity, it is also instrumental. To effectively fulfill the function of creating social order requires more than the knowledge that is inherent in the legal profession, or the one that the lawyers are willing to use while 
"improving law" (i.e. implementing the concept of "good law"). What is almost certain, however, is the fact that the lawyers are also interested in the kind of law that guarantees them certain professional (in some cases maybe even individual) privileges, protects inter-system interests and this is such a law which they, for obvious reasons, regard as "good law" (cf. Z. Zajdalo, 2009: 139).

Looking deeper one can notice that problems with the implementation of the concept of "good law" do not get any smaller when we try to answer the following question: "good law" but good for whom? Who is to be a beneficiary of the process of bettering the law and who is to assess and evaluate the effects of this process?

Answers to these questions should be preceded by an assumption, maybe somewhat limiting, stating that "good law" (in both understandings of this term) is possible only in politically-organized communities (societies). Put it simply, in societies which have created professional, structured and a relatively stable political institution (cf. J.J. Wiatr, 1999: 13 and subsequently K. Pałecki, 2003: 209, and others). Unquestionably, these requirements are met by modern states, although not only. They are also met by inter-state and international organizations as well as ethnic communities aspiring to statehood. By accepting such an assumption I question the position of radical etatism which assigns lawmaking capabilities only to states, which are evidently counter-factual. I also do not agree with a radical approach in the anthropology of law postulating the concept of "primitive law" or "law older than legislation" (cf. F.A. Hayek, 1973: 72 and subsequent). My opinion is based on a consistent lack of demarcation criteria, which allow distinguishing law from other social norms (customs, religion) and, additionally, for the reasons justified by the subject of this analysis. "Primitive law", as a rule it is regarded by those whom it governs, but also sometimes by those who undertake its description, as the best possible option; unquestionable, constantly noble, and legitimized by a stable praxis, hence not suitable to become the subject to any wider sanctions (cf. S.F. Moore, 1978: 13 and subsequent). In this case, implementing the concept of "good law" appears unnecessary; leaving alone the problem of lack of adequate institutions for its application. That is why, there appears to be no need to further analyze this complex problem, 
which, by the way, has been vastly covered in literature. Suffice for the purpose of this analysis is an emerging, as a consequence of the previously accepted assumption, possibility to create a simple typology of categories of agents interested in "good law". It compromises, in the first place, the lawmakers (creators of legal regulations equipped with political power); in the second place, those controlling and executing the application of these regulations; that is in general everybody involved in the application of the law, and - in the third place - difficult to distinguish, subordinate to lawmaking decisions of the first and second categories, addressees of the law, deprived of an ability to directly create law. This classification, although not fully disjunctive, brings in new questions.

Most importantly, it provokes a reflection over the concept (ideal) of a "universally good law", that is law good for everybody included in the above typology (for example good for all citizens). I consider this is a utopian concept and base my opinion on two arguments. First, a practically impossible to overcome difficulty to find objective measures of the degree of "goodness" of the legal system, meaning such measures and measuring techniques which are not interest-driven or designed to protect the position of one of the categories: the lawmakers, the implementers and executors of law, or the addressees of the law. The second argument, easy to justify by numerous observations of political practices, is an unquestionably instrumental treatment of law by political institutions, which use law as a means to succeed in their objectives, programs, protect interests, fulfill "obligations", etc. Their common social acceptance, let alone a chance of reaching a consensus omnium, is rather exceptional in the culturally diverse, socially complex contemporary society. Governance in accordance with what once Hanna Ardent (1969) referred to as act in concert is also of a utopian nature. Hence, most often the attempts to improve law will take place in accordance with the program (objectives, goals and interests) formulated by political institutions. Consequently, new law will rather be "good for the government" or, at most, if a compromise is reached between the interests of the lawmakers and the addressees of the law, it will be "acceptable to the government and the citizens". Depending on the level of autonomy of the legal system, that is its organizational and functional independence of political institutions, 
as well as the degree of isolation from public opinion (demands, postulates of legal civic associations), law, in the sense of regulations included in legal acts and decisions for their application, can be turned into "good", that is in accordance with the beliefs and images of the legal institutions themselves, adequately for the scope of this, always limited, autonomy. It is also quite possible, especially in democratic systems, for some influential associations to force the lawmakers (political institutions) as well as the institutions which apply the law to implement the concept of "good law", although "good" only for a selected social group, i.e. the one represented by these associations, the addressees. This is, quite often, the way, actually quite effective, through which the labour unions operate. Hence, undoubtedly, both the program and the implementation of the concept of "good law" is under pressure by particular categories of a politicallyorganized society. For this reason, improvement of law depends on the net influence of political institutions, legal institutions and civic associations. That is why, as some tend to believe, the best, if not the only way, to make and implement "good law", meaning law free of influence of particular interests, is an institutionally-organized deliberation between all potential addressees of a regulation, which may create, at all stages of the legislative process, binding consequences for formal lawmakers (cf. M. Stepień, 2009: 187 and subsequent). Such deliberation assumes, however, that all social conflicts, which are envisioned to be legally regulated, can be solved, or at least partially solved, through discourse and workedout compromises acceptable to all participants of the discourse. It also assumes a final conclusiveness of such a discourse, at least to the point allowing a formulation of adequate legal regulations. Both assumptions are debatable. A social discussion on problems, which can be solved by means of a legal act, as well as a debate over the "improvement" of law, are often used for expressing emotions, releasing social pressures caused by these problems, or - at times - just to make an impression of active participation in the process of law creation, or - however less often - for some other reason. Lack of conclusiveness of such debates is often a planned effect of manipulation of political institutions, which are interested in avoiding, uncomfortable legislative decisions, as long ago described by Machiavelli (1969 (1532): 41) and brought back to the 
contemporary political science by Peter Bachrach and Morton Baratz through their analyses of the so-called non decision making (1962:947-52). In my opinion, the greatest difficulty in using the open discourse to make "good law" lies in the fact that law may be easier influenced by different manipulations than procedural attempts designed for their elimination.

Summing up, it appears that even the most honest and serious efforts to make "good law" may, at best, be partially beneficial to one group of the social structure, and substantially, only to one fragment of the social order. The idea of the law "good for everybody" is as attractive as it is unreachable. In this way, through reflection over such questions as "how to understand law?" and "what are the categories of its beneficiaries?" we have come closer to another important issue: establishing criteria to assess both the existing law and the one that is still being envisioned, both in terms of the degree of implementation of the concept of "good law". "Good", obviously means "good" to a certain point (in part), or "good" in some aspects, while a law deprived of some characteristic ascribed by these criteria becomes a "bad law" (completely bad, bad to a certain point, bad in some aspects, etc). Only a categorized possibility to make such assessments allows the analyzed concept of "good law" to make any sense.

Historically, the assessment of the law was a typical "transferred" qualification (cf. Pałecki, 1978: 209 and subsequent). The same can be said about our times, and it would not refer to a rare phenomenon. In the Hobbesean tradition the quality of law is decided on by the assessment of the sovereign who makes or executes this law. The task of this assessment is given to the sovereign's subjects. Particular attention is paid to the sovereign's ability to maintain "social order" through effective execution of law, which he had initially made (Leviathan, 1962 (1651): 241 and subsequent). In modern times, especially in Europe, starting with the bourgeois revolutions, an important role was played by the popularity of an opinion on the degree of fulfilling the legitimate requirements by the sovereign to execute power, which also means making and executing law. A refusal of granting such legitimization, just like its approval, was an opinion on the "quality" of law, practically without much regard to the content of regulations or the method of their application in the social order. It was at that time particularly when of particular attractiveness was 
the Roman principle dura lex sed lex. On the other hand, representatives of the historical school of German law were, still at the end of the $19^{\text {th }}$ century, arguing that law "in itself" was principally something good and beneficial (in the tradition of Ulpain's ius est ars boni at aequi). Critique of this assumption, when brought up, (for example in populist ideologies or the works of socialist thinkers) focused only on the lack of particular social characteristics among the lawmakers, which would legitimize them to make "good" law or any law. The quality of law created (executed) by "the government", "the ruling class", "the bourgeois", "the elite", etc. was, hence, a direct consequence the addressees' belief that those in power had adequate qualifications to make law. In this way, the assessment of the broadly understood "lawmakers" (positive or negative) was "transferred" to their legislative outcomes (legal regulations, implementing procedures, etc.). Seemingly even today the criterion of the legitimization of lawmakers serves as a "reference point" in the assessments of the degree of "goodness" of a particular law. And the fact that the subject of so formulated assessment is not the law itself, but rather of lawmaking institutions (and - out of necessity - also political institutions), does not seem to bother anyone.

The $20^{\text {th }}$ century brought a large number of works of philosophers and theoreticians of law which focused - entirely or occasionally - on the problem of relations between legal and moral regulations (while the latter are often associated with authoritarian and postulational concepts of morality, that is with ethical norms). This fact is brought up as a result of placing the word "good" (which - naturally - is contrasted with "bad") in the title of this analysis. However, presenting even a brief summary of the works on this subject would not be possible without a serious violation of their framework. As a pars pro toto let us refer to H.L.A. Hart's The Concept of Law with a very relevant introduction by Jan Woleński ( 1998: XXIII, 251 and subsequent), D. Lyon's Ethics and the Rule of Law (2000: 9 and subsequent, 59 and subsequent), or H. Izdebski's Elements of Theory and Philosophy of Law (2008: 258). The $20^{\text {th }}$ century also witnessed a renewed interest in legal and natural relations, especially as approached by the theorists of international public law (for example the problem of human rights and civil rights - see J. Habermas, 2009: 13 and subsequent, 
J. Woleński, 2006: 31). Consequently, ethical (moral and legal-natural) criteria of law assessment which were highlighted were based on a certain (usually undefined) concept of justice and righteousness (see B. Wojciechowski, M. Golecki, 2008: 10 and subsequent). In some approaches a return to Roman principles could be seen only to deprive certain legal regulations, which, by the way, complied with formal requirements of abiding law, of the role of "being law". This was achieved through bringing back, into the argument, the Aurelian maxim lex iniustissima non est lex, which later became the foundation of Radbruch's critique of the "totalitarian law" (2009: 36 and subsequent) or Paullus' warning non omne quod licet in legibus honestum est, which became the basis for Hayek's "objective of law" Hayek (1973: 12). From the perspective of the implementation, the concept of the "good law", as long as its desired qualities such as "justice", "righteousness", "common good", are not specified operationally (and not only contextually, postulationally, or protectively) they are simply useless. It is just impossible to formulate practical directives of implementing "good law", or directives of sanctions of the already existing legal regulations, which could be clearly interpreted from the morally ambiguous assessments of law. Such assessments may equally well justify a lawmaking directive " $\mathrm{A}$ " with a directive which is contradicting it. This, of course, does not mean that such assessments are not undertaken. Of course, they are and, what is more, frequently become a hidden "missing premise" of the decision made in the process of the application of the law (K. Pałecki, 2004: 17 and subsequent).

Worth presenting are also other arguments supporting a shortcut "dealing" with this quite apragmatic, as I believe, although popular belief that the decision on whether a particular law is good or bad is dependent on the coherence (accordance) of its content with the norms of descriptive and/or normative morality. These "norms" - as I have earlier argued - suffer from an ineradicable illness: they are always indefinable (cf. J. Stelmach, B. Brożek, 2011: 47, I.C. Kamiński, 2003). It means that the number of opportunities to fulfill them is not only very large, but also unlimited. Consequently, the assessment whether in a particular case the moral "norm" was fulfilled or violated, is unavoidably relative and subjective. Beyond the scope of this paper is the enumeration of all reasons behind 
this shortcoming, which can, at times, be the reason not to regard them as norms (at least as "complete" norms), but rather a separate category of general behavioral directives (cf. Pałecki 2003: 43). It is suffice to point to one, although ineradicable. Unquestionably, moral "norms" are used to implement (create, multiply, protect) generalized values such as: "good", "justice", "honesty" etc. These values can, in the social order, be won (protected, multiplied) in an unlimited number of times (in this sense they are inexhaustible). What is more, in practice, they can be achieved, depending on the circumstances, in many ways (in this sense they are sporadic). These characteristics explain the lack of a universal code of moral or ethical behaviour, which, if complied with, would guarantee an unquestionable achievement of these values within a particular society. There are many reasons to call someone good, modest or just. However, without a doubt, there always will be people who will, for different reasons, refuse to assign these qualities to a person who deserves them. More importantly, the requirements of "moral" norms are quite often ambivalent. Meeting the requirements of a "just judgment" can be impossible to balance with the requirement of active compassion. It is probably safe to say that no human society has such a collection of moral directives which would not include a ban on killing other human beings. And yet, as it is well-known, there are communities, who, despite their respect for such a ban, do not condemn certain kinds of homicides or even find reasons for their praising (examples include: revenge killings, killing a criminal who was caught red-handed, killing a "traitor" etc). In Poland, there are many attempts to implement the Constitutional obligation to "implement the principles of social justice" (Article 2). However, some of these attempts, although obtained by legal means are quite controversial and often, as confirmed by the legal practice, the application of one excludes (limits) the application of another (cf. S. Tkacz, 2008: 21 and subsequent). Similar examples are large in numbers. Summing up: moral "norms" as a criterion of the degree of "goodness" of law, due to the method of regulation as well as its subject matter, are too unclear to serve as a basis for an assessment of law, which could further serve as establishing "adequate" implementation of the concept of "good law". Put it differently. An arbitrarily decision on how to implement this concept, as well as abstaining from such an attempt, 
will find, without problems, justification in a moral assessment of law. Beyond the scope of this paper it is a discussion on other difficulties arising from applying moral criteria in such assessments, for example, establishing the level of coherence between the content of legal norms and moral directives.

The same may, although not necessarily, be said about religious norms when treated as a criterion used in the assessment of the degree of "goodness" of law. Religious norms tend to be quite undefined, but also the opposite, very precise and even casuistic in their demands (for example the Koran laws banning the consumption of pork and alcohol). Nonetheless, even in cases when religious norms straightforwardly establish specific duties of conduct, there still may be problems with applying them as a criterion to assess law. Some individuals' rejection of faith or even its mere questioning (as, for example, in the case of the atheists or reformers) deprives this criterion of legitimacy to create a binding assessment of law. The argumentation goes: "since I do not believe in God, then why should I follow his orders while instituting law". Of course theological "recommendations" may be given adequate consideration in the process of lawmaking for other than their origin reasons (for example due to a real or implied effectiveness in preventive illnesses, effective procreation, stability of family relations, etc.). However, in these cases, they become completely different criteria of law assessment (for example, the criteria which refer to medical, psychological, sociological knowledge, etc.). It is worth pointing out that with the exception of the most radical theological doctrines, and in cases where religion is tightly integrated with the legal system, nobody questions the fact that the non-believers or secular institutions can make good law.

Accepting a broader perspective, which is not limited to morality and religion, we can notice that accepting the content of any norm, other than legal norms, as a criterion for assessing legal norms can pose serious difficulties in cases when implementing the concept of "good law" leads to some sort of innovation. In cases, when these other norms show an already significant inertia and, what is more, have become common and internalized "for a long time" in a given society, any attempt to introduce, by means of law, a new conduct model, could be assessed as a deterioration, and not 
an improvement, of the current state of law. This could happen even in cases, when -based on well-documented knowledge - it is clear that new law could prove to be, for various reasons, better than the existing one (cf. M.B. Arctowa, 1967:236). As a rule, morality and religion, more than law, appear to be less susceptible to innovative changes.

Moral (ethical) criteria of assessing the degree of "goodness" of law, meaning the criteria which are external to the legal system, should not be confused with the criteria comprising the so-called internal morality of law, as in the well-known concept of Lon Fuller (2004). The case in question is a collection of principles established by lawyers, particularly in practice and judicial reflection, whose violation undermines the duty to abide legal regulations (legal decisions) and makes law not as much "morally bad" but "possible to question in terms of abiding" and, as a result, ineffective. A typical example of such validative functioning of "internal" legal principles is, for example, a commonly respected canon: lex non obligat nisi promulgate (law is not obligatory unless it is promulgated, or in a stricter version, faultily promulgated). Nonetheless, one cannot exclude that the implementation of the concept of "good law" may, to some degree, translate into implementation of requirements included in those "internal" principles of law. Paradoxically, accepting the principles of "internal morality of law" as a basis for implementing the concept of "good law" is not so obvious. This is due to the fact that they establish certain standards whose fulfillment turns particular legal regulations (decisions) into law in general, as opposed to its substitute, an ersatz of law, and even "lawlessness in the form of law". These are the characteristics of the tout court law, any law deserving this name, which is later, due to its other characteristics and assessment criteria, can turn out to be both a "good" and a "bad" law (obviously with a certain acceptance of the grading of such assessment). There is yet another obstacle to the application of principles of internal morality of law to its possible improvement, that is each of those accepted principles is later "excluded" from application in practice through different lex specialis, that is "unusual", "extraordinary", "temporary", "transitioning" regulations, which are always more detailed than the principles and quite often justified by such beliefs as: the existing law is in danger of being spoilt or a "bad law" is being created (that is, for example, 
the one which is created for political gain). The principles of "internal morality of law" are constantly accompanied by hypocritical behaviour of lawmakers: none of them undermines their legitimacy but, at the same time, it is impossible to find a system of legal acts, which would not include any exceptions to these requirements.

The "internal morality of law" is related to the principles of "technical" qualities of the legal system, that is a logical and transparent order of legal acts, clarity of language, coherence of requirements included in provisions, etc. In this case, "good law" would have to meet the requirements of the so-called legislative technique, which, in its evaluation, would allow us to ignore the content of the provisions. Such an approach is difficult to reconcile with a common belief that "good law" is such law whose substantial requirements remain in accordance with commonly accepted axiological beliefs. The fact that law, which is "good" in a formal sense (technically, procedurally, and in terms of effectiveness) can easily prove to be substantially (that is in terms of content) "bad" is rather a commonplace. The real problem lies in finding an answer to the question whether it is possible to achieve a substantially good law (meaning such law which is axiomatically accepted by its addressees and judicial institutions), with a simultaneous negligence of its desired formal qualities (technical, instrumental). It is easy to notice that this is a more detailed version of a question already asked; meaning whether poorly, faultily functioning institutions applying the law can create a substantially "good" law?

I dare provide a negative answer to this question. Even the most justified regulations, yet poorly formulated, violate system principles of ordering, promulgation procedures, etc. They also lose their substantial justification in the process of their application due to formal inadequacies (shortcomings). They will gradually, and maybe unavoidably, become subject to a content depreciation (por. A. Michalska, S. Wronkowska, 1983: 167). Hence is a need for subsequent "remedial" functional interpretations, which can not only completely modify, but also eliminate original intentions of lawmakers. I would suggest that such a threat be taken seriously, especially by those impatient and "efficient" legislators who are driven by the rule "let us first make a necessary law and later worry about its cosmetic polishing". 
Analogically to technical flaws of legal regulations, dysfunctional institutions, that is those which are incompetent, poorly-organized, poorly-equipped, unable to keep certain personal standards, but which apply and execute law, can, in the process of making individual and concrete decisions, very easily devalue a substantially and formally "well" formulated law. This could happen, for example, due to corruption. In implementing the principle of "good law" it is impossible - which should be stressed time and again - to ignore organizational, technical and personality characteristics of legal institutions, meaning the same characteristics as those applicable to political institutions, and concentrate only on a formal and substantial quality of legal regulations.

To complete the existing typology of criteria of assessment of legal acts, let us refer to two criteria, which are quite often confused (mixed together), namely: effectiveness and economy of law. Both of these criteria find a relatively large space in the contemporary discourse of legal science (see J. Stelmach, B. Brożek, W. Załuski, 2007). Let us assume, with a certain necessary simplification, that effective law (and depending on the degree of this effectiveness adequately "good" or "bad") is such law whose application leads to reaching a desired outcome with a greater degree of probability than a haphazard or unexceptional one. In turn, for law to be an economic means such as an application of a legal act which results in a gain (in an economic sense), that is; its effect is of a greater market value than the quantitatively measured inputs necessary to obtain it. The size of this gain also marks the degree in which the law which was "implemented" for its achievement is assessed as "good" or "bad". However, both criteria are quite problematic. The most effective law can easily be used to achieve non-noble, undesirable aims (which are unethical) and it is - from different sources - known that law often achieves such effectiveness through applying particularly strict and difficult to accept sanctions. Hence, effective law may become "bad law" - while accepting all but theological criteria - which is the reason, why it is effective. Keeping in mind that the winding roads of policy-making sometimes allow for situations in which it "makes sense" for politicians to apply the law in a way which is planned to be ineffective, at least for reasons for which it was introduced, but which is effective for other reasons, which are usually covered. An example: 
gaining popularity among the voters. Putting aside such practices, the assessment of the effectiveness of law remains an uneasy task for the following reasons: its goals are either gradual and cannot be subject to an objective observation, or are of a dynamic, changeable nature.

A reduction of the concept of "good law" to the application of effective law depends on accepting certain, not always revealed, and somewhat dubious assumption that the lawmakers, while formulating normative regulations, have a good enough knowledge on the relations between activities undertaken for implementing requirements imposed by these regulations and the emergence of the planned (desired) results. In other words, the problem of effective legislation is limited to adequate diligence in obtaining good knowledge (infallible in terms of cause-and-effect propositions) and its adequate application in the content of the regulations and norms. And yet, a casual observation of the effects of legislative processes leads to an assumption that even regulations included in the socalled technical norms (hence, norms which oblige their addressees to apply technologies derived from advances in different scientific disciplines (especially natural sciences) can lead to consequences which are both undesirable and unwelcomed. And what would happen if we completely entrusted the engineers of social sciences? In social sciences, there are constant methodological disputes regarding the adequacies of formulated sentences (theories), which suggests that lawmaking institutions would have to be competent enough to select statements (theories, predictions, expertise, recommendations) which are "the best" from "all available", which are often of a conflicting message, before they could decide to articulate the content for normative regulations as based on such theories. Difficulties with an adequate application of judicial expertise, which are well-known to all lawyers, prove that fulfilling this requirement would not be realistic.

Similar objections can be directed towards accepting the criterion of the "economy of law" as the one which decides on the degree to which a particular law is "good". Additionally, this criterion is not applicable when the "profits," resulting (expected) from the application (abiding) of legal regulations, are not of a quantitative nature, or are not transferable into any kind of good (it cannot be used in market transactions of goods and 
services). Examples: when a "profit" of an applied law is an increased trust in public administration or an increased sense of safety. It is easy to notice that "good law" in an economic sense - just like effective law - can simultaneously introduce and execute regulations which are not acceptable in a particular system of ethics (ideological, religious) or by commonly accepted moral beliefs (for example, capital punishment for the crime of ineffective economic management, which is foreseen and executed by the legal system in the People's Republic of China). In these cases, we are dealing with "bad law".

Summing up, an abstract concept of making "good law" is not transferable into any practical directives. Its nature is that of an emotive message. The reasons for its postulate are outside the legal system and attempt at creating specific social reactions (for example gaining voters' support). The concept of "good law" can be given a pragmatic sense only by specifying the vision of desired social order for which "law" (legal system) will be used as an implementation instrument. Not the only one, but a crucial one. In turn, a desired social order will easily become another foggy idea or a subject of interest-based manipulation, if it is not derived from a precisely articulated order of values and objectives, i.e. axiological order, which is to be applied. Although not a necessary and sufficient condition, particular features of an axiological order decide on the degree of adequateness of this "derivation". Overly generalizing the values-objectives, which are to be reached by means of law, and disregarding the order of mutual relations inside the collection of such values, especially individual values, which mark the sequence of activities undertaken to "improve law", occasionally, dictated by "current interests", introduction to this collection of "alternative" values, there are only a few faults of the axiological order, which result in its complete or significant apragmatism. Additionally, I believe that the idea of axiologically (ideologically) neutral making, or even more, applying of the law, which can constantly be heard in projects proposed at improving the law and which is "good" due to its immanent, formal and substantial qualities, is a utopia. At the same time, I believe that using basic ethical categories for the assessment of law, its "good" or "bad" nature, is a misunderstanding resulting from a mental shortcut and a particular facon de parler used in oral speeches. An assessment of exist- 
ing or/and foreseen effects of law, substantial and non-substantial, is automatically transferred to the law itself, in the content of regulations, and actions undertaken by institutions. And yet, the "law" itself, and even a particular legal norm, is almost never "assigned" to an individual objective (value-objective) or to an individual result of its application. It can also be of intrinsic value, not necessarily an instrumental one. Although it is always used to achieve something and, from the perspective of particular ethics or/and morality, this "something" can be more adequately decided on whether it is "good" or "bad". And yet despite this fact, the transfer of assessment of the effects of law on the law itself (a norm, an institution) is a far-reached simplification and assumes an existence of a casual relation between fulfilling legal requirements and an emergence of specific social facts (phenomena). This relationship quite often has to be excluded in more thorough investigations. The process of evaluating law, which is an exit point for the process of implementing the concept of "good law", resembles an evaluation of other much simpler instruments. Consider a knife. When used for slicing bread, a knife can generate only positive assessments. However, the very same knife, used as a murder weapon, generates the opposite assessments. Commonly we would say that in the first case the knife is "good" and "bad" in the second case, although its qualities have, in fact, not changed. In reality, the knife is neither "good" nor "bad". It is sharp or blunt, short or long, etc. For this reason, it has different kinds of usefulness which determine (casually) for which purpose it will be used. Thus, maybe the concept of "good law" should be understood similarly, not directed to the legal system itself, but rather to the real intentions of the lawmakers. Then the assessment of law could be reduced to the assessment of the degree of its application in the implementation of intended goals, this time already "good" or "bad", and consequently the same assessment of those who plan to implement their intended goals by means of law. An implementation of the concept of "good law" would then be a procedure focused on creating the awareness of the latter. Finally, by making a rather large circle of thoughts, we are returning to a rather old idea: law is as "good" as the sovereign who makes it. 


\section{BIBLIOGRAPHY}

Alexy R. (2007), O pojęciu i naturze prawa, „Ius at Lex”, No. 1.

Arendt H. (1969), On violence, [in:] Power, ed. S. Lukes, N.Y.U.P.

Bachrach P., Baratz M. (1962), The Two Faces of Power, "American Political Science Review", No. 56.

Black D. (1976), The Behavior of Law, New York.

Borucka-Arctowa M. 1967, O społecznym działaniu prawa, Warszawa.

Fuller L. (2004), Moralność Prawa, Warszawa.

Gizbert-Studnicki T. (2001), Ujęcie instytucjonalne w teorii prawa, [in:] Studia z filozofii Prawa, Kraków.

Grabowski A. (2009), Prawnicze pojęcie obowiązywania prawa stanowionego. Krytyka niepozytywistycznej koncepcji prawa, Kraków.

Habermas J. (2009), The Constitutionalization of International Law and the Legitimation Problems..., [in:] Between Complexity of Law and Luck of Order, eds. B. Wojciechowski, M. Zirk-Sadowski, M.J. Golecki.

Hart H. (2001), Amerykańska teoria prawa widziana angielskimi oczami. Nocna mara i szlachetny sen, (1977), [in:] Eseje z filozofii prawa, Warszawa.

Hart H. (1998), Pojęcie prawa, Warszawa.

Hayek F.A. (1973), Rules and Order, London.

Hobbes T. (1962), Leviathan, Londyn (1651).

Hoebel A.E. (1954), The Law of Primitive Man, Cambridge.

Hyden H. (2010), Law-making as a Compromise Between an Internal and External Dimension of Law, "Papers of Polish-Swedish Project", Lund - Kraków.

Izdebski H. (2008), Elementy teorii i filozofii prawa, Warszawa.

Kamiński I.C. (2003), Słuszność i prawo, Kraków.

Kelsen H. (1973), Law and Morality, [in:] Essays in Legal and Moral Philosophy, Boston.

Lyons D. (2003), Etyka i rządy prawa, Warszawa (2000).

Machiavelli M. (1969), Książe, Warszawa.

Malinowski B. (2001), Prawo, zwyczaj, zbrodnia w społeczności dzikich, Warszawa.

Michalska A., Wronkowska S. (1983), Zasady tworzenia prawa, Poznań. 
Moore S.F. (1978), Law as Process. An Anthropological Approach, London.

Pałecki K. (2003), Prawoznawstwo, zarys wykładu. Prawo w porządku społecznym, Warszawa.

Pałecki K. (1978), Społeczne opinie o prawie i jego stosowaniu..., [in:] Poglady społeczeństwa polskiego na stosowanie prawa, ed. M. Borucka-Arctowa Warszawa.

Pałecki K. (2004), Stressing Legal Decisions. Basic Assumptions, [in:] Stressing Legal Decisions, T. Biernat (ed.), Kraków.

Radbruch G. (2009), Filozofia prawa, Warszawa.

Raz J. (1979), The Authority of Law, Oxford.

Stelmach J., Brożek B., Załuski W. (2007), Dziesięć wykładów o ekonomii prawa, Warszawa.

Stelmach J., Brożek B. (2011), Sztuka negocjacji prawniczych, Warszawa.

Stępień M. (2009), Dobre prawo a mechanizmy demokracji liberalnejzarys problematyki, [in:] Dobre prawo, złe prawo - w kręgu myśli Gustawa Radbrucha, Kraków-Warszawa.

Tkacz S. (2008), O czym myślimy mówiąc o sprawiedliwości społecznej?, [in:] Rozdroża Sprawiedliwości...

Wiatr J.J. (1999), Socjologia polityki, Warszawa.

Wojciechowski B., Golecki M.J. (2008), Rozdroża sprawiedliwości we współczesnej myśli filozoficzno-prawnej, Toruń.

Woleński J. (2006), Czy prawo naturalne daje się uzasadnić?, [in:] Prawo, Władza, Społeczeństwo, Polityka, Toruń.

Zajadło J. (2009), Wewnętrzna legitymacja Sądu Konstytucyjnego, "Przegląd Sejmowy", No. 4(93). 